\title{
Pengembangan Inventori Perkembangan Siswa (IPS)
}

\author{
Kasmayani Anwar \\ Bimbingan dan Konseling, Progam Pascasarjana Universitas Negeri Makassar, Indonesia \\ Email: kasmayanianwar@gmail.com
}

\author{
Abdul Saman \\ Bimbingan dan Konseling, Universitas Negeri Makassar, Indonesia \\ Email: abdulsaman@gmail.com
}

(Diterima: 20-April-2018; di revisi:11-Mei-2018; dipublikasikan: 29-Juni-2018)

\begin{abstract}
The study aims to find out (1) an overview of the needs analysis for the use of Student Development Inventories (IPS). (2) How is the prototype for developing student development inventory (IPS), (3) the level of validity, reliability and feasibility of developing a Student Development Inventory (IPS) as one of the data collection tools in State High School 9 Bulukumba. Research is a research or development research involving 15 high school students in a small group trial. The results showed (1) Student development inventory (IPS) as a measuring instrument / instrument is very needed, in the form of updates or updates in terms of form, content and problem areas of BK and too many statement items that make students tired of reading and filling inventory. (2) Prototype Student development inventory (IPS) developed in full with manuals, so that guidance and counseling teachers can use inventory. (3) the results of the trial obtained the value of student development inventory validity (IPS) are on a scale of 4.17 at the stage of validity expert test with valid criteria, the value of reliability test obtained high criteria or reliable, so it can be concluded that student development inventory (IPS) with a number of 76 items that are valid, reliable statements can be used as student development inventories (IPS)
\end{abstract}

Keywords: Development Inventory.

\begin{abstract}
Abstrak: Penelitian bertujuan untuk mengetahui (1) gambaran analisis kebutuhan terhadap penggunaan Inventori Perkembangan Siswa (IPS). (2) Bagaimana prototype pengembangan inventori perkembangan siswa (IPS). (3) tingkat validitas, relibilitas dan kelayakan pengembangan Inventori Perkembangan Siswa (IPS) sebagai salah satu alat pengumpulan data di SMA Negeri 9 Bulukumba. Penelitian merupakan penelitian pengembangan atau research and development melibatkan 15 siswa SMA dalam uji coba kelompok kecil. Hasil penelitian menunjukkan (1) Inventori perkembangan siswa (IPS) sebagai alat ukur/ instrumen sangat dibutuhkan, berupa pembaharuan atau update dari segi bentuk, isi dan bidang permasalahan BK serta item pernyataan yang masih terlalu banyak yang membuat para siswa bosan membaca dan mengisi inventori.(2) Prototype Inventori perkembangan siswa (IPS) yang dikembangkan lengkap dengan manual, sehingga guru bimbingan dan konseling dapat mempergunakan inventori. (3) hasil uji diperoleh nilai validitas inventori perkembangan siswa (IPS) berada pada skala 4,17 pada tahap uji ahli validitas dengan kriteria valid, nilai dari uji reliabilitas diperoleh 0,66 atau 96,6\% dengan kriteria tinggi atau reliable, sehingga dapat disimpulkan bahwa inventori perkembangan siswa (IPS) dengan jumlah 76 item pernyataan yang valid, reliabel dapat digunakan sebagai inventori perkembangan siswa (IPS) di SMA Negeri 9 Bulukumba.
\end{abstract}

Kata Kunci: Inventori Perkembangan Siswa.

This is an open access article under the CC BY-NC 4.0 license

(http://creativecommons.org/licenses/by-nc-nd/4.0/) 


\section{PENDAHULUAN}

Sekolah sebagai lembaga pendidikan formal diperlukan kerjasama sejumlah orang dalam mencapai suatu tujuan untuk menghasilkan peserta didik yang berkualitas. Guru memiliki peran sentral dalam proses pembelajaran termasuk guru bimbingan dan konseling. Guru bimbingan dan konseling adalah guru yang memiliki kemampuan dan kualitas kepribadian yang baik, memiliki pengetahuan dan keahlian profesional tentang pelayanan bimbingan dan konseling, psikologi pendidikan yang sesuai dengan tugas dan profesinya. Berdasarkan SK Menpan No. 84/1993 menegaskan bahwa tugas pokok guru bimbingan dan konseling (BK) yaitu:

"Menyusun program bimbingan, melaksanakan program bimbingan, mengevaluasi program bimbingan, analisis hasil pelaksanaan bimbingan dan tindak lanjut dalam program bimbingan terhadap peserta didik yang menjadi tanggungjawabnya" (Depdiknas, 2002)

Masalah yang terjadi dalam dunia pendidikan sangat kompleks, baik yang berhubungan dengan kurikulum, fasilitas pendidikan, guru dan siswa pada khususnya.Kerena itu, peran guru bimbingan dan konseling harus ekstra sabar dan mau bekerja ekstra untuk meluangkan waktunya memahami lingkungan sekitarnya (dalam sekolah) karena peran guru bimbingan dan konseling adalah mencegah agar tidak terjadi masalah dan memutuskan masalah apabila sesuatu telah terjadi.

Sekolah Menengah Atas (SMA) merupakan salah satu bentuk satuan pendidikan yang menyelenggarakan pendidikan tiga tahun setelah sekolah menengah pertama.Secara psikologis, siswa usia SMA memasuki masa remaja. Masa remaja biasa juga disebut dengan masa adolesensi yaitu tumbuh menjadi dewasa atau fase adaptif dari perkembangan kepribadian, fase mencoba-coba (Alwisol, 2005: 128).Istilah adolesensi mempunyai arti yang lebih luas, mencakup kematangan mental, emosional, sosial, dan fisik.

Masa remaja merupakan masa yang mudah bergolak dan keguncangan. Perkembangan emosional dalam tahap ini masih 2 labil, dan penuh kegoncangan. Masa remaja biasa dianggap sebagai periode "badai dan tekanan" suatu masa dimana ketegangan emosi meninggi sebagai akibat dari perubahan fisik dan kelenjar (Hurlock, 2006: 212).
Dalam masa usia transisi yang dialami remaja ini, cenderung membawa dampak psikologis di samping membawa dampak fisiologis, dimana perilaku mereka cenderung berfikir pendek dan ingin cepat dalam memecahkan berbagai permasalahan kehidupan. Sebagaimana Hurlock (2006: 208) mengemukakan bahwa masa remaja dikatakan sebagai masa yang tidak realistis. Karena proses berfikir yang tidak realistis tersebut, remaja kadang tidak mampu membedakan hal baik atau buruk untuk dijadikan acuan perilaku, bahkan remaja sering tidak memperhatikan perilaku yang sesuai dengan konsep "halal dan haram" sesuai perintah dan larangan agama yang dianutnya. Akhirnya tidak jarang remaja khususnya usia SMA yang terjerumus dalam kasus-kasus yang melanggar norma, baik norma sosial maupun norma agama, seperti: tawuran antar pelajar, video porno, miras dan obat-obat terlarang, sex pranikah dan sebagainya. Fenomena demikian menun-jukkan masih kurangnya kontrol dan rendahnya kecerdasan emosional remaja.Hal ini menjadi perhatian seluruh personil yang ada di sekolah salah satu yang berperan penting adalah guru bimbingan dan konseling.

Salah satu kegiatan guru Bimbingan dan konseling adalah merumuskan Program kegiatan, Jenis layanan, dan isi bimbingan dan konseling dirumuskan atas dasar kebu-tuhan nyata dan kondisi objektif perkembangan siswa.Kondisi objektif perkembangan siswa yang dipahami melalui analisis tugas-tugas perkembangan dapat menghasilkan profil perkembangan siswa yang menjadi dasar bagi pengembangan program bimbingan dan konseling.Layanan bimbingan yang didasarkan atas dan berorientasi kepada pencapaian tugastugas perkembangan siswa dapat menumbuhkan kesadaran guru pembimbing bahwa program dan layanan bimbingan dan konseling disekolah mutlak harus berdasar kepada kebutuhan dan perkembangan siswa.

Keberhasilan individu dalam men-capai tugas perkembangan juga dipengaruhi oleh kesempatan dan bimbingan untuk mempelajari tugas perkembangan sesuai dengan usia perkembangannya. Individu yang memperoleh banyak bimbingan dari orang tua akan lebih mudah dalam memahami tugas perkembangan yang harus dicapai sehingga tugas perkembangan yang dicapai individu tersebut dapat lebih optimal dibandingkan dengan individu yang tidak memperoleh bimbingan dari 
orang tua. Bimbingan untuk mempelajari tugas perkembangan dapat dilakukan oleh orang tua kepada anak saat di rumah dengan memberikan perhatian kepada anak saat melakukan kegiatan belajar, mendorong dan memotivasi anak untuk belajar, memberi reinforcement setelah anak melakukan kegiatan belajar dan memberikan bimbingan belajar ketika anak mengalami kesulitan dalam belajar. Kesempatan dan bimbingan orang tua kepada anak untuk mempelajari tugas perkembangan akan menumbuhkan motivasi belajar sehingga anak akan terbiasa belajar tanpa ada paksaan dari orang lain. Hurlock terjemahan Meitasari Tjandrasa (1978:201) berpendapat beberapa sumbangan keluarga pada perkembangan anak antara lain menjadi sumber kasih sayang dan penerimaan, menjadi orang yang di harapkan bantuannya dalam menyelesaikan masalah, sebagai sumber persahabatan sampai mereka besar ketika tidak ada teman di luar. Salah satu instrument yang bisa digunakan untuk mempelajari perkembangangan siswa adalah inventori

Inventori merupakan suatu alat untuk mengungkap, menaksir atau mengidentifikasi keadaan pribadi siswa serta menilai ada atau tidaknya tingkah laku dan sikap tertentu yang harus diselesaikan. Biasanya inventori berbentuk daftar pernyataan yang harus dijawab melalui hasil chek-list sesuai dengan keadaan pribadi masing-masing.(Anastasi \& Urbina, 2007).

Inventori merupakan bagian dari beberapa instrumen pengumpulan data tentang diri siswa.Inventori bagian dari teknik nontesting yang dimaksudkan teknik penilaian untuk memperoleh gambaran terutama mengenai karakteristik, sikap atau kepribadian.Inventori yang saat ini digu-nakan dalam pelayanan $\mathrm{BK}$ adalah alat ungkap masalah (AUM) adalah sebuah alat yang digunakan untuk mengungkapkan masalahmasalah pribadi siswa.Selain dari, instrumen alat ungkap masalah (AUM) dan Inventori tugas perkembangan (ITP) ada beberapa instrumen pengumpulan data yang dapat digunakan untuk memperoleh gambaran mengenai karakteristik, sikap, atau kepribadian diantaranyadiantaranya observasi , interview, angket, daftar chek masalah (DCM), otobiografi, kunjungan rumah, kotak masalah, dokumentasi, daftar pribadi, case studi, case history, catatan anekdot, pedoman wawancara.

Melihat dari segi kelemahan atau kekurangan yang didapatkan dari ITP yang digunakan selama ini di sekolah-sekolah khususnya di SMA.Terkadang hanya dijadikan sebagai pajangan karena berbagai kekurangan yang ada misalnya butir item pernyataan yang banyak, tidak update, dan terlalu banyak bidang masalah yang dibahas. Maka inventori ini akan dibuat lebih praktis, valid dan reliabilitas serta lebih update sesuai dengan analisis kebutuhan yang menyangkut masalah perkembangan pada bidang kognitif, moral, emosi dan sosial khususnya pada kalangan siswa jenjang SMA sementara kalimat dari butir-butir pernyataan akan dibuat lebih singkat, padat, jelas dan sederhana (butir-butir pernyataannya lebih sedikit) dalam penampilan maupun penyelenggaraan yang tidak akan membuat kejenuhan ataupun perasaan kebosanan dalam membaca serta dapat menghasilkan data yang lebih objektif.

Inventori Perkembangan Siswa (IPS) adalah sebuah instrumen atau invetori yang di kembangkan berdasarkananalisis tugas-tugas perkembangan siswa yang dapat menghasilkan produk profil perkembangan siswa yang menjadi dasar pengembangan program layanan bimbangan dan konseling, berupa pernyataanpernyataanyang terdiri dari perkembangan kognitif, social, emosi dan moral.

Berdasarkan wawancara awal pada tanggal 24 januari 2017 dengan konselor yang ada disekolah bahwa kebayakan permasalahan yang terjadi disekolah menyangkut tugas perkembangannya, dimana siswa tidak mampu melihat apa-apa saja yang seharusnya mereka lakukan sesuai dengan tugas perkembangannya. Keba-nyakan siswa melakukan hal-hal melampaui batas umur mereka dan sering kali mengabaikan tugas perkembangannya sesuai dengan umur mereka saat sekarang.

Dari hasil survey melalui wawancara, penyebaran angket kepada siswa dan observasi langsung di lapangan mengingat peneliti merupakan salah satu alumni di sekolah tersebut, diketahui bahwa belum adanya inventori perkembangan siswa (IPS) yang sesuai dengan taraf kemampuan siswa. Oleh karena itu, peneliti akan melakukan penelitian dan pengembangan inventori perkembangan siswa (IPS) untuk membantu guru BK dalam kelancaran program BK maupun siswa dalam menganalisis tugas-tugas perkembangan yang dialami oleh siswasehingga guru BK dapat menyusun program layanan bimbingan dan konseling yang efektif dan tepat sasaran buat siswa. 
Inventori secara khusus dalam bidang psikologi yaitu sebagai alat ukur atau instrumen yang digunakan untuk mengukur dan mengungkap ada atau tidak adanya perilaku atau sikap yang dimiliki seseorang, biasanya berupa daftar pertanyaan atau pernyataan yang harus dijawab responden sesuai dengan keadaan dirinya.Dalam inventori ini tidak ada jawaban benar atau salah.Semua daftar pernyataan dijawab sesuai dengan kondisi masing-masing res-ponden.

IPS merupakan instrument yang dirancang untuk mengidentifikasi kebutuhan nyata dan kondisi objektif perkembangan peserta didik di jenjang pendidikan SMA. Hasil penelitian Ema Sahwa (2008 : 137) tentang pengembangan instrumen alat ukur kematangan siswa mengatakan bahwa testing psikologis itu penting untuk membuat diagnosis psikologis apalagi yang berkaitan dengan suatu pengukuran untuk siswa.

Hasil Penelitian Asaruddin (2013: 6) tentang pengembangan instrumen sikap dan minat pada pembelajaran mengatakan bahwa pengembangan suatu instrumen sangatlah penting dan berguna bagi siswa dan guru karena dapat mempermudah dan mengetahui apa yang dimiliki dan dibutuhkan siswa kita.

Berdasarkan penelitian Erni Marlina (2014) tentang Instrumen inventori peminatan karir bidang keahlian Bisnis Manajemen dan manual atau pentunjuk penggunaan Invetori peminatan karir (IPK). Hasil penelitian menunjukkan bahwa Inventori peminatan karir bidang keahlian manajemen sangat dibutuhkan oleh SMK, selanjutnya prototype Inventori dinyatakan layak digunakan oleh beberapa ahli dan Hasil uji coba menunjukkan bahwa produk telah memenuhi kriteria kepraktisan dan keefektifan.
Dengan begitu peneliti berinisiatif untuk mengembangkan Inventori Perkembangan Siswa (IPS)yang bertujuan untuk menganalisis tugastugas perkembangan siswa yang dapat menghasilkan produk profil perkembangan siswa yang menjadi dasar pengembangan program bimbingan dan konseling.

\section{METODE}

Penelitian ini dilakukan dengan menggunakan pendekatan" Penelitian Pengembangan" (research and development). Menurut Borg dan Gal/l (2003), yang dimaksud dengan model penelitian dan pengembangan adalah " a process used develop and validate educational product". Kadang-kadang penelitian ini juga disebut 'research based development', yang muncul sebagai strategi dan bertujuan untuk meningkatkan kualitas pendidikan.

Selain untuk mengembangkan dan memvalidasi hasil-hasil pendidikan, research and development juga bertujuan untuk menemukan pengetahuan-penge-tahuan baru melalui 'basic research', atau untuk menjawab pertanyaan-pertanyaan khusus tentang masalahmasalah yang bersifat praktis melalui 'applied research', yang digunakan untuk meningkatkan praktik-praktik pendidikan. Penelitian ini research and development dimanfaatkan untuk menghasilkan inventori per-kembangan siswa (IPS) sehingga kemampuan institusi dalam memberikan layanan dapat berkembang.

Borg dan Gall (2003) memberikan batasan tentang penelitian pengembangan sebagai usaha untuk mengembangkan dan menvalidasi produk-produk yang digunakan dalam pendidikan.

Tabel. 3.2 Keadaan subjek penelitian pengembangan inventori perkembangan siswa (IPS)di SMA Negeri 9 Bulukumba

\begin{tabular}{|c|c|c|c|}
\hline $\begin{array}{l}\text { Tahap Kegiatan } \\
\text { Penelitian }\end{array}$ & Jenis Subjek & Jumlah & Keterangan \\
\hline Analisis kebutuhan & $\begin{array}{ll}\text { - Konselor } \\
\text { - Siswa }\end{array}$ & $\begin{array}{c}1 \\
20\end{array}$ & $\begin{array}{l}\text { SMA Negeri } 9 \text { Bulukumba } \\
\text { Kelas XI }\end{array}$ \\
\hline Validasi ahli & $\begin{array}{ll}\text { - } & \text { Ahli psikologi } \\
\text { - } & \text { Pakar konseling } \\
\text { - } & \text { Praktisi BK }\end{array}$ & $\begin{array}{l}1 \\
1 \\
1\end{array}$ & $\begin{array}{l}\text { 1.Ahli Psikologi } \\
\text { 2.Pakar Konseling } \\
\text { 3.Praktisi BK }\end{array}$ \\
\hline $\begin{array}{l}\text { Uji coba Inventori } \\
\text { IMS kelompok kecil }\end{array}$ & - Siswa XI & 15 & Perwakilan kelas XI \\
\hline $\begin{array}{l}\text { Uji Validitas dan } \\
\text { reliabilitas }\end{array}$ & - Angket inventori IPS & 76 item & $\begin{array}{l}\text { Angket yang telah diisi pada } \\
\text { masing-masing siswa yang telah } \\
\text { dijadikan uji coba IPS }\end{array}$ \\
\hline
\end{tabular}




\section{HASIL DAN PEMBAHASAN}

Berdasarkan hasil need assessment yang diperoleh di sekolah melalui wawancara penelitian dengan kepala sekolah guru bimbingan konseling dan beberaapa orang siswa dikemukakan bahwa inventori perkembangan siswa sangat diperlukan disekolah karena bisa membantu konser mengetahui tingkat perkembangan siswa. Asesmen kebutuhan ini dilakukan untuk mengetahui bagaimana gambaran awal pelaksanaan pengembangan. Untuk itu, assesmen kebutuhan diarahkan untuk memperoleh gambaran mengenai bagaimana penggunaan inventori ITP, eksistensi, urgensi, bentuk pelaksanaan, signifikansi, pelaksanaan pengembangan Inventori Perkembangan Siswa (IPS) di SMA Negeri 9 Bulukumba.

Eksistensi pengembangan Inventori Perkembangan Siswa (IPS) untuk siswa adalah belum adanya alat ukur atau instrumen yang bertujuan untuk mengidentifikasi tugas-tugas perkembangan siswa yang terdiri dari 4 aspek perkembangan layanan bimbingan konseling dan memiliki item pernyataan yang sedikit sehingga siswa tidak menjadi jenuh dan bosan dalam mengerjakannya dan hasinya pun bisa maksimal dalam mengidentifikasi tugas-tugas perkembangan siswa.

Dari hasil survey melalui wawancara, penyebaran angket kepada siswa dan observasi langsung di lapangan, diketahui bahwa belum adanya inventori Perkembangan Siswa (IPS) yang sesuai dengan taraf kemampuan siswa. Oleh karena itu, peneliti akan melakukan penelitian dan pengembangan Inventori Perkembangan Siswa (IPS) untuk membantu guru BK dalam kelancaran program BK maupun siswa dalam mengidentifikasi perkembangan yang dialami siswa dalam upaya merancang program layanan bimbingan dan konseling yang efektif dan tepat sasaran buat siswa.

Hasil gambaran kebutuhan siswa yang dilakukan oleh peneliti tidak hanya didasarkan pada asumsi-asumsi dalam menganalisis kebutuhan saja tetapi juga pada hasil studi pendahuluan yang dilakukan di sekolah, dengan menggunakan teknik survey melalui wawancara (interview) dengan siswa dan guru BK beserta penyebaran angket yang berkaitan dengan pengembangan inventori yang akan disusun oleh peneliti.

Prototype inventori awal yang telah dirumuskan dilakukan validasi untuk memperoleh inventori yang memiliki kelayakan isi dan praktis. Berdasarkan validasi isi, diperoleh hasil yang menunjukkan bahwa semua aspek atau isi yang ada pada prototype Inventori Perkembangan Siswa (IPS) dinilai oleh ahli psikologi, ahli BK dan Praktisi Bk di lapangan yang bertindak selaku validator telah memiliki kelayakan konseptual yang memadai. Validasi ahli dilakukan dengan mangajukan prototypeInventori Perkembangan Siswa (IPS) untuk kemudian dilakukan uji kelayakannya.

Secara keseluruhan hasil validasi yang dilakukan kepada ketiga ahli, hasil yang diperoleh, validator mengapresiasi pengembangan Inventori Perkembangan Siswa (IPS) untuk diterapkan di sekolah. Namun masih ada saran-saran perbaikan yang diberikan guna penyempurnaan pengembangan inventori Perkembangan Siswa (IPS). Hal ini dilihat dan disimpulkan berdasarkan hasil angket validasi ahli yang telah diisi oleh ketiga ahli. Hasil uji validitas yang telah dilakukan dijadikan sebagai bahan revisi inventori sebelum diujikan ke lapangan secara langsung.

Selanjutnya diujicobakan kembali kelapangan sebanyak 5kali ujicoba kelompok kecil dan pada setiap uji coba dilaksanakan wawancara, focus group discussion(FGD) pada jenjang pendidikan tingkat SMA dan pada siswa yang beragam dari kelas XI, dalam rangka perbaikan tata bahasa dan pengaturan kalimat pada inventori IPS tersebut, dalam uji kelompok kecil karena dalam IPS tersebut banyak tata bahasa yang kurang dipahami atau dimengerti oleh siswa, kemudian instrumenInventori Perkembangan Siswa (IPS) diujicobakan kembali sampai dengan tahap akhir.

Pada tahap yang kelima item-item pernyataan sebanyak 76 item dalam Inventori Perkembangan Siswa (IPS) yang dinyatakan konsisten tersebut diperbaiki kembali tata bahasa yang kurang dipahami dan kurang dimengerti oleh siswa dalam pelaksanaan wawancara, focus group discussion (FGD) kepada para siswa-siswi serta dilakukan sharingterhadap guru BK demi kelayakan dan keberterimaan produk IPS tersebut sehingga dinyatakan hasil bahwa IPS yang valid, reliabel, praktis dan dapat digunakan sebanyak 76 item dalam penyebaran 4 aspek perkembangan yaitu aspek sosial, emosi, moral, dan intelektual.Berdasarkan hasil tersebut, yang didapatkan mulai dari langkah awalassesmen kebutuhan yang dilakukan sampai dengan tahap akhir revisi akhir, maka didesainlah alat ukur atau perangkat yang diberi nama Inventori 
Perkembangan Siswa (IPS) sebagai perangkat dalam mengidentifikasi masalah perkembangan siswa dan menjadi sebuah produk Inventori Perkembangan Siswa (IPS) yang valid, reliabel, dan layak digunakan di jenjang pendidikan SMA Negeri 9 Bulukumba.

Dari hasil penelitian pengembangan yang menghasilkan sebuah produk IPS masih memiliki beberapa keterbatasan penelitian antara lain: kemampuan peneliti dalam mengembangakn produk masih tahap terbatas, produk inventori IPS hanya sebatas dapat digunakan pada jenjang tingkat SMA dan hanya pada sebatas wilayah atau lingkungan sekolah SMA Negeri 9Bulukumba, pengembangan penelitian hanya sebatas sampai ujicoba kelompok kecil pada siswa yang berbeda namun pada sekolah yang sama sehingga memerlukan pengujian pada tingkat yang lebih luas atau diujicobakan pada jenjang tiap-tiap sekolah agar dapat digunakan oleh semua pihak sekolah yang membutuhkan sehingga penelitian ini diharapkan dikembangkan kembali pada peneliti selanjutnya demi menghasilkan produk yang lebih menuju kesempurnaan.

Prototype Kebutuhan Sekolah Terhadap Instrumen Inventori Perkembangan Siswa Dalam perencanaan pengembangan yang dilakukan dalam pengembangan inventori yang dirancang dalam bentuk manual atau prototype inventori merujuk pada empat aspek perkembangan yaitu, moral, kognitif, emosi dan sosial.

Prototype inventori awal yang telah dirumuskan dilakukan validasi untuk memperoleh inventori yang memiliki kelayakan isi dan praktis.Berdasarkan validasi isi, diperoleh hasil yang mennjukkan bahwa semua aspek atau isi yang ada pada prototype inventori perkembangan siswa dinilai pada ahli psikologi dan ahli konseling yang bertindak sebagai validator telah memiliki kelayakan konseptual yang memadai. Validasi ahli dilakukan dengan mengajukan prototype inventori perkembangan siswa yang akan dikembangkan menjadi dua tahap yaitu melalui tahap wawancara kepada tiga ahli untuk menentukan validitas prototype inventori perkembangan siswa kemudian dilakukan uji akseptibilitas yang mencakup ; kegunaaan, kelayakan serta ketepatan pada inventori perkembangan siswa.

Secara keseluruhan hasil validasi yang dilakukan kepada ketiga ahli, hasil yang diperoleh, validator megapresiasi pengembangan inventori perkembangan siswa yang dikembangkan untuk segera diterapkan di sekolah-sekolah. Namun masih ada saran-saran yang diberikan guna penyempurnaan pengembangan inventori perkembangan siswa . Hal ini dapat dilihat dan disimpulkan berdasarkan hasil wawancara dan angket akseptibilitas yang diisi oleh ketiga ahli.Hasil uji validitas yang telah dilakukan dijadikan sebagai bahan revisi inventori sebelum diujikan ke lapangan secara langsung.

Berdasarkan hasil assesmen kebutuhan yang dillakukan, maka didesainlah alat ukur yang diberi nama inventori perkembangan siswa sebagai alat ukur untuk mengetahui tugas-tugas perkembangan siswa SMA Negeri 9 Bulukumba. Inventori ini dapat diimplementasikan sebagai alat ukur dalam mengetahui tugas-tugas perkembangan siswa di sekolah. Prototype perkembangan di uraikan sebagai berikut ;

Pendidikan nasional berfungsi mengembangkan dan membentuk watak serta peradaban bangsa yang bermartabat dalam rangka mencerdaskan kehidupan bangsa, bertujuan untuk berkembangnya potensi peserta didik agar menjadi manusia yang beriman dan bertakwa kepada Tuhan Yang Maha Esa, berakhlak mulia, sehat, berilmu, cakap, kreatif, mandiri, dan menjadi warga negara yang demokratis serta bertanggung jawab". Pendidikan dianggap sebagai alternatif yang bersifat preventif karena pendidikan membangun generasi muda bangsa yang lebih baik.Pendidikan diharapkan dapat mengembangkan kualitas generasi muda bangsa dalam berbagai aspek yang dapat memperkecil dan mengurangi penyebab berbagai masalah budaya dan karakter bangsa. Kurikulum adalah jantungnya pendidikan (curriculum is the heart of education). Oleh karena itu, sudah seharusnya kurikulum, saat ini, memberikan perhatian yang lebih besar pada pendidikan budaya dan karakter bangsa dibandingkan kurikulum masa sebelumnya.

Dasar pertimbangan penyelenggaraan pelayanan bimbingan dan konseling di Sekolah, bukan semata-mata terletak pada ada atau tidak adanya landasan hukum (perundang-undangan) atau ketentuan dari pemerintah tetapi yang lebih penting adalah upaya memfasilitasi peserta didik agar mampu mengembangkan potensi dirinya guna mencapai tugas-tugas perkembangannya dalam aspek fisik, emosi, intelektual, sosial, dan moral-spiritual. Proses pendidikan harus dipandang sebagai suatu proses perkembangan, 
karena setiap peserta didik sebagai individu sedang berada dalam proses berkembang atau menjadi (becoming), yaitu berkembang ke arah kematangan atau kemandirian. Untuk mencapai kematangan tersebut, peserta didik memerlukan bimbingan karena mereka masih kurang memiliki pemahaman atau wawasan tentang dirinya dan lingkungannya juga pengalaman dalam menentukan arah kehidupannya. Di samping itu terdapat suatu keniscayaan bahwa proses perkembangan individu tidak selalu berlangsung secara mulus, atau steril dari masalah. Dengan kata lain, proses perkembangan itu tidak selalu berjalan dalam alur linier, lurus, atau searah dengan potensi, harapan dan nlai-nilai yang dianut. Untuk itulah diperlukan pelayanan bimbingan dan konseling yang dirancang secara baik agar mampu menfasilitasi individu kearah kematangan dan kemandirian. Hal ini diperkuat dengan adanya perbedaan individual pada peserta didik dan keniscayaan bahwa proses perkembangan peserta didik tidak selalu berlangsung secara mulus, dalam alur yang lurus, searah dengan potensi, harapan dan nilai-nilai yang dianut, sehingga banyak individu yang memerlukan bantuan orang lain.

Proses penelitian ini diawali dengan penyusunan instrument, yaitu IPS (Inventori Perkembangan Siswa) sebagai upaya untuk melakukan "need assessment". Perumusan IPS didasarkan kepada kepada hasil penelahaan terhadap tugas-tugas perkembangan para peserta didik dijenjang pendidikan SMA.

Inventori Perkembangan Siswa (IPS) adalah instrumen yang digunakan untk memahami tingkat perkembangan siswa dari segi perkembangan moral, kognitif, sosial dan emosi.Penyusunan IPS terutama dimaksudkan untuk menunjang kegiatan bimbingan dan konseling di sekolah, namun dapat juga digunakan untuk mengetahui tingkat perkembangan anak-anak dan pemuda pada umumnya.

Inventori Perkembangan Siswa (IPS)sebagai instrument non tes bimbingan konseling untuk meningkatkan pemahaman dan memperkirakan masalah-masalah yang dialami siswa.Inventori Perkembangan Siswa (IPS)sebagai instrument atau alat bimbingan konseling berdasarkan penilaian ahli. Validitas bentuk dan isi ialah ketepatan rancangan bentuk dan isi prototipe bimbingan dan konseling melalui Inventori Perkembangan Siswa (IPS)yang diperoleh melalui penilaian ahli.
Sekolah memiliki pengaruh besar dalam perkembangan dan kehidupan remaja karena remaja menghabiskan sebagaian besar waktunya di sekolah (Marin \& Brown, 2005).Sekolah merupakan tempat belajar formal dilaksanakan serta pusat kehidupan sosial remaja.Oleh karena itu, siswa remaja perlu merasa.sejahtera ketika berada di sekolah.

Masa remaja sering disebut sebagai masa "badai" akibat adanya perubahan tugastugas dan tuntutan perkembangan.Remaja perlu dipersiapkan agar dapat melewati masa ini dengan baik.Jika remaja tidak mampu melewatinya dengan baik, kemungkinan mengalami gangguan psikologis menjadi lebih besar. Hal ini disebabkan oleh upaya adaptasi terhadap tugas-tugas dan tuntutan baru memicu kelelahan emosi, kognitif, dan sosial remaja (Bizarro, 2006; Compas, 1993).

Program kegiatan, Jenis layanan, dan isi bimbingan dankonseling dirumuskan atas dasar kebutuhan nyata dan kondisi objektif perkembangan siswa.Kondisi objektif perkembangan siswa yang dipahami melalui analisis tugas-tugas perkembangan dapat menghasilkan profil perkembangan siswa yang menjadi dasar bagi pengembangan program bimbingan dan konseling.Layanan bimbingan yang didasarkan atas dan berorientasi kepada pencapaian tugas-tugas perkembangan siswa dapat menumbuhkan kesadaran guru pembimbing bahwa program dan layanan bimbingan dan konseling disekolah mutlak harus berdasar kepada kebutuhan dan perkembangan siswa..

\section{SIMPULAN DAN SARAN}

Berdasarkan hasil penelitian dan tahapan pengembangan inventori perkembangan siswa (IPS) ,maka dapat ditarik kesimpulan yaitu: (1) Inventori perkembangan siswa (IPS) sebagai alat ukur/instrument sangat dibutuhkan di sekolah SMA Negeri 9 Bulukumba, oleh karena gambaran kebutuhan siswa terhadap inventori perkembangan siswa (IPS) masih membutuhkan pembaharuan atau update dari segi bentuk, isi dan bidang permasalahan BK serta item pernyataan yang masih terlalu banyak yang membuat para siswa bosan membaca dan mengisi inventori yang ada di sekolah tersebut; (2) Prototype Inventori perkembangan siswa (IPS) yang dikembangkan sesuai dengan tujuan yang ingin dicapai, oleh karena peneliti 
melengkapi dengan manualnya, sehingga guru bimbingan dan konseling dapat mempergunakan inventori tersebut; (3) Inventori perkembangan siswa (IPS) yang dikembangkan telah sesuai dengan tujuan yang ingin dicapai, oleh karena peneliti telah melalui langkah-langkah uji coba dalam pengembangan inventori perkembangan siswa (IPS), sehingga berdasarkan hasil yang diperoleh yaitu: nilai validitas inventori perkembangan siswa (IPS) berada pada skala 4,17 pada tahap uji ahli validitas dengan kriteria valid, nilai dari uji reliabilitas diperoleh 0,66 atau $96,6 \%$ dengan kriteria tinggi atau reliabel. Sehingga dapat disimpulkan bahwa inventori perkembangan siswa (IPS) dengan jumlah 76 item pernyataan yang valid, reliable dapat digunakan sebagai inventori perkembangan siswa (IPS) di SMA Negeri 9 Bulukumba.

Berdasarkan hasil penelitian yang telah dilakukan dan dinyatakan layak untuk digunakan dan memberikan implikasi kepada berbagai pihak sehingga direkomendasikan terhadap pengembangan ilmu pengetahuan, dinas pendidikan dan kebudayaan, sebagai pemecah masalah pendidikan, sekolah SMA yaitu (1) Pengembangan ilmu pengetahuan, hasil penelitian ini menunjukkan bahwa inventori perkembangan siswa (IPS) sebagai alat ukur baik dari segi konseptual maupun dari segi praktis memiliki kelayakan untuk diimplementasikan di sekolah. Dari segi pengembang ilmu model ini dapat memberikan konstribusi bagi pengembang ilmu bimbingan dan konseling; (2) Dinas pendidikan dan kebudayaan atau pemecah masalah pendidikan, inventori perkembangan siswa (IPS) ini didasarkan pada kebutuhan akan adanya suatu alat ukur yang dapat digunakan oleh guru BK dalam membantu siswa mengidentikasi masalahnya. Karena inventori perkembangan siswa (IPS) ini dapat membantu mengidentifikasi masalah perkembangan siswa dan membantu guru BK dalam membuat rancangan program layanan bimbingan dan konseling di sekolah yang berbasis kebutuhan siswa.

Sekolah pada jenjang SMA dapat mempergunakan inventori perkembangan siswa
(IPS) karena inventori ini valid dan reliable dan telah divalidasi oleh beberapa ahli.

$$
\text { Peneliti selanjutan, agar }
$$

mengembangkan inventori perkembangan siswa (IPS) atau produk pada skala uji coba yang lebih besar pada beragam sekolah agar dapat digunakan pada skala beberapa sekolah tidak hanya pada satu sekolah saja tetapi beberapa sekolah khususnya jenjang SMA demi kesempurnaan produk yang akan dihasilkan dan inventori ini baru dikembangkan dan kemungkinan besar masih banyak hal-hal yang perlu dilengkapi terutama dari segi efiktifitasnya, oleh karena itu direkomendasikan untuk dapat menelaah atau mengembangkan inventori ini pada sasaran yang beragam misalnya pada jenjang SD, SMP dan SMA.

\section{DAFTAR RUJUKAN}

Anastasi, A \& Urbina, 2007. Tes Psikologi. Jakarta: PT. Indeks

Asaruddin. (2013). Tesis Pengembangan sikap dan minat. Pascasarjana : UNM.

Borg,Water .R \& Gall.Meredith.D. (2003). Educational research : an introduction. America.

Depdiknas. (2002). Panduan Pelayanan Bimbimbingan dan Konseling Berbasis Kompetensi SMP, Madrasah, Tsanawiyah, Sederajat. Jakarta : Pusat Kurikulum Balitbang Depdiknas.

Ema, Sahira. (2008). Tesis Instrument Alat Ukur Kematangan. Pascasarjana: UNM.

Erni, Marlina. (2014). Tesis Pengembangan Alat Ukur Kematangan Karir. Pascasarjana: UNM.

Ketut, D dan Made, D. (1990). Pedoman Praktis Bimbingan Penyuluhan di Sekolah. Jakarta: Rineka Cipta.

Sahwa, E. (2008). Pengembangan Instrument Alat Ukur Kematangan. Tesis. Pascasarjana:UNM

Undang-Undang Republik Indonesia No.20 Tahun 2003 tentang Sistem Pendidikan Nasional (SISDIKNAS). 2003. Bandung: Citra Umbara 